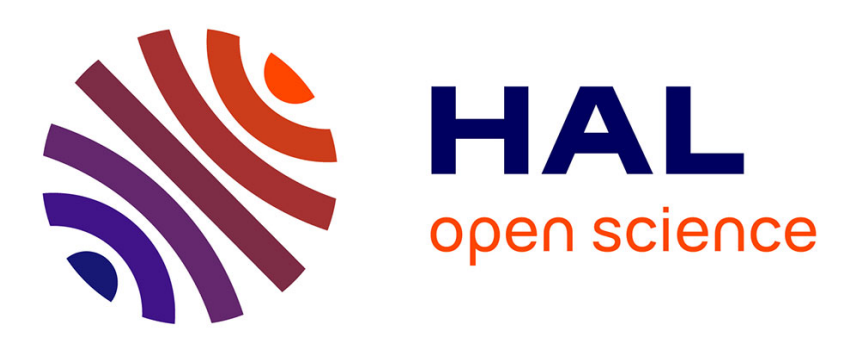

\title{
Seasonal influence of the sea surface temperature on the low atmospheric circulation and precipitation in the eastern equatorial Atlantic
}

Remi Meynadier, Gaëlle de Coëtlogon, Marion Leduc-Leballeur, Laurence Eymard, Serge Janicot

\section{To cite this version:}

Remi Meynadier, Gaëlle de Coëtlogon, Marion Leduc-Leballeur, Laurence Eymard, Serge Janicot. Seasonal influence of the sea surface temperature on the low atmospheric circulation and precipitation in the eastern equatorial Atlantic. Climate Dynamics, 2016, 47 (3), pp.1127-1142. 10.1007/s00382015-2892-7 . insu-01229906

\section{HAL Id: insu-01229906 https://hal-insu.archives-ouvertes.fr/insu-01229906}

Submitted on 8 Nov 2018

HAL is a multi-disciplinary open access archive for the deposit and dissemination of scientific research documents, whether they are published or not. The documents may come from teaching and research institutions in France or abroad, or from public or private research centers.
L'archive ouverte pluridisciplinaire HAL, est destinée au dépôt et à la diffusion de documents scientifiques de niveau recherche, publiés ou non, émanant des établissements d'enseignement et de recherche français ou étrangers, des laboratoires publics ou privés. 
1 Seasonal influence of the sea surface temperature on the low atmospheric circulation and precipitation in the Eastern

5 Rémi Meynadier (1), Gaëlle de Coëtlogon (2), Marion Leduc-Leballeur (3), Laurence Eymard (4) and

6 Serge Janicot (4)

7 1. LA (Toulouse)

8 2. LATMOS-IPSL (Paris)

9 3. LGGE (Grenoble)

10 4. LOCEAN-IPSL (Paris)

12 Abstract

13 The Air-Sea interaction in the Gulf of Guinea and its role in setting precipitation at the

14 Guinean coast is investigated in the present paper. This study is based on satellite

15 observations and WRF simulations forced by different sea surface temperature (SST) patterns.

16 It shows that the seasonal cold tongue setup in the Gulf of Guinea, along with its very active

17 northern front, tends to strongly constrain the low level atmospheric dynamics between the

18 equator and the Guinean coast. Underlying mechanisms including local SST effect on the

19 marine boundary layer stability and hydrostatically-changed meridional pressure gradient

20 through changes in SST gradient are quantified in WRF regarding observations and CFSR

21 reanalyses. Theses mechanisms strongly impact moisture flux convergence near the coast,

22 leading to the installation of the first rainy season of the West African Monsoon (WAM)

23 system. The current study details the mechanisms by which the Atlantic Equatorial cold

24 tongue plays a major role in the pre-onset of the boreal WAM. 


\section{Introduction}

27 The northern Gulf of Guinea is marked by a heavy coastal rainfall in April - May, which is 28 generally intense during 2 to 3 weeks, and stops about one week before the onset of the

29 Sahelian phase of the West African monsoon (Thorncroft et al. 2010, Nguyen et al. 2011). The

30 latter is suspected to be strongly conditioned by the continent, with an important role played

31 by the Saharan Heat Low in West Africa (Lavaysse et al. 2009). The monsoon jump (i.e the

32 rapid shift of precipitation from the Guinean coast to the Sahel) occurs also because of

33 dynamical instabilities developing at the end of the coastal precipitation phase (Cook 2015).

34 Coastal convection is likely inhibited because of the subsidence of dry air induced by a

35 westward Rossby wave generated after the Indian monsoon onset (Flaounas et al. 2012). It

36 has been shown that the sea surface temperature (SST) in the Gulf of Guinea played a key

37 role in the West African Monsoon. The intensification and the northward seasonal migration

38 of the South Atlantic anticyclone (Sta Helena) induces an acceleration of the Trade winds in

39 the southeastern Tropical Atlantic in boreal spring and summer, cooling the SST into an

40 equatorial "cold tongue" between roughly $4^{\circ} \mathrm{S}$ and $1^{\circ} \mathrm{N}$ (Caniaux et al. 2011, Marin et al.

41 2009, de Coëtlogon et al. 2010, Jouanno et al. 2013, Giordani et al. 2013). A consequence of

42 the northern front of the cold tongue is to accelerate the overlying surface wind, as suggested

43 for interannual (Caniaux et al. 2011) and intraseasonal (de Coëtlogon et al. 2010, 2014)

44 timescales. Moreover, the development of the cold tongue during the boreal spring controls

45 the Guinean coastal rainfall (GCR) in May-June (Thorncroft et al. 2010, Leduc-Leballeur et

46 al. 2011), through the onset of a low-level atmospheric circulation (LLAC) between the

47 equator and the coast (Leduc-Leballeur et al. 2013). The implied mechanism is linked to

48 changes in Sea Level Pressure (SLP) gradient induced by the strengthened meridional SST

49 gradient in the Northern Front of the Cold Tongue (NFCT, de Coëtlogon et al. 2014, Caniaux

50 et al. 2011), according to the mechanism described in Lindzen and Nigam (1987). It then

51 increases the transport of moisture towards the coast (Thorncroft et al., 2010), encouraging

52 convection to develop there. This mechanism will be called afterward "LN" (as "Lindzen and

53 Nigam"). 
54 Another mechanism of Tropical Atlantic SST influence on surface wind is linked with the 55 vertical mixing of the wind momentum in the marine atmospheric boundary layer (MABL), 56 which decreases over a colder SST because of an increased stability in the lower atmospheric

57 column (Sweet al. 1981, Wallace et al. 1987, Hayes et al. 1987). Stability is also increased by 58 tropospheric subsidence occurring at the equator, suppressing deep convection when the cold 59 tongue is well established (Yin and Albrecht 2000). This mechanism will be called afterward 60 "SW" (as "Sweet and Wallace"). De Coëtlogon et al. (2014) showed significant hints of both 61 of these mechanisms in daily observations and reanalyses at short timescales (a few days), but 62 not at seasonal timescales. The connection between the NFCT and the GCR is therefore 63 investigated in this study at the seasonal scale.The tested hypothesis is that the NFCT forces 64 both the wind speed increase between the equator and the Guinean coast, and the northward 65 migration of the precipitation toward the coastal region. Numerical simulations are performed 66 with the non-hydrostatic regional Weather Research and Forecasting WRF model (Skamarock 67 et al., 2008) forced by different observed SST. The analysis aims at quantifying the cold 68 tongue influence on low level dynamics and further explore its impact on the water cycle.

69 The numerical simulations discussed in this paper are based on composites around a reference 70 date, thereafter Tref, of the LLAC and Guinean coastal rainfall (GCR) onset, which was 71 defined in Leduc-Leballeur et al. (2013). Section 3 thoroughly describes the Tref definition 72 and the air-sea coupling for a 2-month composite period around Tref in the observations, the 73 meteorological reanalyses, and the WRF simulations. Section 4 focuses on the mechanisms 74 modifying the low-level atmospheric circulation induced by SST seasonal variability and the 75 quantitative estimation of the underlying processes in the WRF simulation. The importance of 76 the atmospheric forcing at the model domain boundaries versus the SST influence are tested 77 in four additional experiments, detailed in section 5. The last section presents a short 78 discussion and summary of the results. 


\section{2. Data}

Surface wind vectors were provided by the QuikSCAT (Quick Scatterometer) satellite

83 (Liu et al. 2000) available on the Remote Sensing Systems website (www.remss.com), as 3-

84 day running mean on a $0.25^{\circ} \times 0.25^{\circ}$ grid between 2000 and 2009 . A two-dimensional cubic-

85 spline interpolation first filled the gaps due to the clouds for each available day, and then a

86 linear temporal interpolation at each grid point completed the 15 missing days over the

87 decade.

88 The high-resolution SST product developed using optimum interpolation, the

89 Advanced Very High Resolution Radiometer (AVHRR) infrared satellite SST data, and in situ

90 data from ships and buoys (Reynolds et al. 2007) have been retrieved thanks to the NOAA-

91 NCDC (National Oceanic and Atmospheric Administration - National Climatic Data Center)

$92 \mathrm{ftp}$ site (http://www.ncdc.noaa.gov), with a spatial grid resolution of $0.25^{\circ}$ and at a daily

93 temporal resolution.

94 In addition, the daily averaged TRMM 3B42 V7 product on a $0.25^{\circ} \times 0.25^{\circ}$ grid was

95 used. It mixes satellite measurements from microwave sensors and infrared geostationary

96 instruments with data from ground radars (Huffman et al. 2007), which guarantees the best

97 possible quality for precipitation data. It was retrieved from the website trmm.gsfc.nasa.gov.

98 Reanalysis from the Climate Forecast System Reanalysis (CFSR, Saha et al. 2010)

99 were retrieved from the National Centre for Environmental Prediction (NCEP) site

100 (www.ncep.noaa.gov). One of the distinctive CFSR characteristics is that it was performed

101 with a coupled ocean-atmosphere model, which was shown to better describe the air-sea

102 interaction in the eastern Tropical Atlantic than the ERA-interim (European centre for

103 meddium-range weather forecasts Re-Analysis, de Coëtlogon et al. 2014). The data are

104 available on a $0.5^{\circ} \times 0.5^{\circ}$ horizontal grid, with vertical atmospheric profiles retrieved on 27

105 levels from 1000 to $100 \mathrm{hPa}$. Daily means of the 6-hourly parameters were used over the 
2000-2009 decade.

\section{Composites around the LLAC / GCR onset date (Tref)}

110 Leduc-Leballeur et al. (2013) defined a reference date to study the abrupt change observed in

111 the surface wind pattern between April and July in the eastern equatorial Atlantic, due to the

112 cold tongue and NFCT development. This date, hereafter referred as Tref, corresponds to the

113 onset of strong southerlies between the equator and the Guinean coast (more exactly, Tref is

114 the date when southerlies become - and remain until fall - stronger at $2^{\circ} \mathrm{N}-3^{\circ} \mathrm{N}$ than just south

115 of the equator, see their paper for more details). They showed that this date corresponds to the

116 GCR onset using satellite precipitation data, and to the LLAC installation between the equator

117 and the Guinean coast as seen in atmospheric reanalyses (NCEP CFSR and ERA-Interim).

118 Fig. 1 defines the Tref date for each year, from 2000 to 2009. Among them, note two 119 particular years : the earliest Tref in 2005 (May 11), and the latest in 2006 (June 25). Note that 120 years 2005 and 2006 are known for exhibiting a large difference in the properties of the 121 equatorial cold tongue. Marin et al. (2009) showed that far colder temperatures were observed 122 in 2005 than in 2006. This difference results mainly from a time shift in the development of

123 the cold tongue between the two years, due to different surface wind speed conditions in 124 April-May, thus explaining why Tref is earlier in 2005 than in 2006. This large interannual 125 variability prevents the regular daily seasonal average in May-June of being pertinent for a 126 clear view of the seasonal changes in the observations, hence the need for a composite built 127 around Tref.

128 The seasonal composite around Tref (i.e. daily averages around Tref for the period 2000129 2009) marks clearly the time of a strong SST cooling between roughly $4^{\circ} \mathrm{S}$ and $1^{\circ} \mathrm{N}$ (Fig. 3 130 bottom row), while the wind accelerates north of the equator and decelerates further south 131 (middle row). In addition, Tref corresponds to a northward seasonal shift of the rainfall (top 132 row): after Tref, no more rainfall is indeed observed south of $2^{\circ} \mathrm{N}$ in the Gulf of Guinea. The 
133 intense GCR lasts about 2 weeks before the Sahelian "monsoon jump". In this composite, the

134 mean observed seasonal GCR clearly lasts about 2 weeks, while the rain completely stops

135 south of $2^{\circ} \mathrm{N}-3^{\circ} \mathrm{N}$ (top left). The coastal shift of precipitation also coincides with the

136 intensification of the oceanic NFCT (more than $0.6 \mathrm{~K}$ per lat. deg. after Tref, bottom left).

137 In addition to this clear seasonal evolution around Tref, a very large intraseasonal variability 138 can be observed yearly (not shown) in the equatorial region and further south, with a 139 dominant timescale of about 2 weeks, which is probably due to a strong SST / surface wind 140 coupling (with a negative feedback) in the equatorial region (see de Coëtlogon et al. 2010, 141 2014). Although these quasi-biweekly timescales are considerably damped in the 2000-2009 142 composites around Tref, as seen in Fig. 3 (left column), they are however still visible in the 143 observed surface wind and SST composites, emphasizing the importance of the quasi144 biweekly oscillations for the phasing of the GCR onset, as discussed in Leduc-Leballeur et al. 145 (2013). However, the intraseasonal variability will not be further discussed here, as the scope 146 of this study is to rule out the mechanisms behind the rapid seasonal shift around Tref.

148 The configuration of WRF version 3.3 and parameterizations used in this study are chosen to 149 produce realistic surface wind and rainfall patterns in May - June (see Meynadier et al. 2014). 150 WRF physics is based here on Betts-Miller-Janjic (Betts,1986 ; Betts et Miller, 1986 ; Janjic , 151 1994) scheme for the cumulus scheme, Yonsei University (YSU, Hong et al., 2006a) non152 local closure PBL scheme, RRTMG for the short and long-wave radiation schemes and the 153 single moment six-class (WSM6) scheme (Hong et al., 2006b) for microphysics. The 154 horizontal resolution is set at $25 \mathrm{~km}$ with 35 vertical sigma levels and a top-of-atmosphere at $15550 \mathrm{hPa}$. The simulation domain is similar to the one used in Meynadier et al. (2014) and was 156 chosen to be wide enough in latitude and longitude for WRF to fully simulate "by itself" the 157 large scale atmospheric features (such as the African Easterly Jet) of the West African climate 158 system.

159 A 2-month numerical simulation with WRF was designed to represent the average seasonal 
160 evolution around Tref. ERA Interim data for years 2000 to 2009 were averaged in 6-hour 161 composites around Tref ( 1 month before and 1 month after), and used to force the regional 162 model boundaries, except for the SST field. For the latter, the surface input forcing over the

163 ocean was composited around Tref using satellite-based daily Reynolds dataset (seen in Fig. 1643 , bottom row).

165 A time-latitude diagram of this WRF simulation for the $10^{\circ} \mathrm{W}-0$ meridional band shows that 166 the precipitation simulated by the model is almost twice too abundant. Its evolution during the 167 seasonal transition (phasing around Tref + latitudinal distribution) matches the observed 168 composite quite well (Fig. 3, top middle). The evolution of the simulated surface wind pattern 169 is also in agreement with the observations, except that the wind speed is about 1 to $3 \mathrm{~m} / \mathrm{s}$ too 170 weak (middle row). This northerly bias is the strongest between the equator and the Guinean 171 coast, where the actual southerlies can actually reach $8 \mathrm{~m} / \mathrm{s}$ on average. A similar bias was 172 also found in reanalyses (see de Coëtlogon et al. 2014), as can be seen here for the CFSR 173 reanalyses (Fig. 3, right column), in spite of the assimilation of QuikSCAT surface wind 174 observations. One can note that WRF SST is not exactly similar to Reynolds SST used to 175 force the model but shows slightly smaller values. WRF SST shown here is actually surface 176 skin temperature (SKT) from the WRF ouput. c. Transition patterns around the LLAC onset

178 The abrupt seasonal transition around Tref was examined by comparing the parameters at two 179 different times, before and after Tref:

180 period $1=[$ Tref-3 weeks : Tref-1 week]. On average : 10-24 May.

181 period $2=$ [Tref : Tref +2 weeks $]$. On average : $1-14$ June.

182 The two periods (also sketched in Fig. 1) are 2 weeks long each, thereby partly damping the 183 large quasi-biweekly variability observed in the equatorial region.

184 Fig. 4 (surface wind and SST) and Fig. 5 (precipitation and precipitable water, thereafter 
185 PWAT) show the parameters averaged within each of these two periods, as well as their 186 difference (i.e. [period 2] minus [period 1]). The top row shows the observations, the middle 187 row shows the WRF simulation, and the bottom row shows the wind bias in the model 188 relative to the observations.

189 The surface wind speed is generally too weak in the simulation, as mentioned in the previous 190 section, by about $1 \mathrm{~m} / \mathrm{s}$, and up to $3 \mathrm{~m} / \mathrm{s}$ north of the equator (Fig. 4, bottom row). Before Tref 191 (period 1), this bias stands south of $5^{\circ} \mathrm{N}$, with a slightly stronger-than-normal wind near the 192 Guinean coast; but after Tref, the bias largely increases near the coast (period 2). Since the 193 wind bias is actually maximal downstream of the SST front, particularly after Tref near the 194 coast, it may suggest that the NFCT impact on the surface wind acceleration is not strong 195 enough in the model,compared to the observations. The bias could also come from flaws in 196 the forcing fields at the model boundaries, or from the model itself, especially near West 197 Africa coast, where the numerical representation of the continental surface wet conditions still 198 remains a challenge (Taylor 2008) and could impact the near-shore low-level atmospheric 199 circulation.

200 Although much too abundant in the simulation, the precipitation spatial distribution is very 201 similar to the observations (Fig. 5): with a realistic slight deviation from the zonal symmetry, 202 it exhibits a clear northward migration from as far south as the equator before Tref to a 203 maximum near the Guinean coast after Tref, and no more rainfall south of $2-3^{\circ} \mathrm{N}$. The PWAT 204 pattern also follows this steep northward shift before and after Tref, with a pattern similar in 205 the simulation than in the observations, pending a small dry bias.

206 Let us remind here the two main mechanisms through which the SST possibly influences the 207 surface wind:

$208 *$ Sweet and Wallace (SW) mechanism: the cold tongue reduces the wind speed through the 209 vertical stability of the lower atmospheric boundary layer. As discussed for example in de 210 Coëtlogon et al. (2014), this effect is immediate and local, and confined in the lower part of 
211 the boundary layer (or mixed layer), and it is well observed in the vicinity of the cold tongue,

212 where the SST cooling and wind speed weakening are maximal (i.e. in the [ $\left.1^{\circ} \mathrm{S}-\mathrm{Eq}\right]$ band).

$213 *$ Lindzen and Nigam (LN) mechanism: an increased SST gradient accelerates the overlying 214 wind through a hydrostatically-induced increased pressure gradient (in absolute values), 215 possibly advected by the mean atmospheric flow. Here, on average, the meridional SST 216 gradient is maximal in $\left[\mathrm{Eq}-1^{\circ} \mathrm{N}\right]$, and the southerlies crossing the equator in $\left[2.5^{\circ} \mathrm{N}-3.5^{\circ} \mathrm{N}\right]$ 217 (i.e. 100 to $200 \mathrm{~km}$ downstream of the SST front).

218 The vertical extension of the SST impact is documented with latitudinal-vertical sections of 219 the model output, averaged between $10^{\circ} \mathrm{W}$ and $0^{\circ} \mathrm{E}$. Fig. 6 shows period 1, period 2, and their 220 difference (i.e. [period 2] minus [period 1]), for the meridional velocity (shadings) and 221 meridional gradient of geopotential height (thereafter dZ/dy, black contours) up to $500 \mathrm{hPa}$. It 222 shows that $\mathrm{dZ} / \mathrm{dy}$ is negative south of the equator in the whole troposphere, traducing the 223 presence of the South Atlantic anticyclone (Fig. 6a and 6b). But further north, close to and 224 over the continent (north of $5^{\circ} \mathrm{N}$ ), its pattern is more complex than would give a "classical 225 Hadley circulation", with a symetric positive dZ/dy: because of the strong meridional thermal 226 contrast between the eastern Tropical Atlantic and West Africa, dZ/dy is strongly negative 227 within or near the atmospheric boundary layer, and strongly positive overhead.

228 The seasonal abrupt transition of the meridional low-level atmospheric circulation from 229 period 1 to period 2 is clearly seen in Fig. 6: the middle of the LLAC (i.e. subsident/ 230 convective cell between the equator and the Guinean coast) is indeed shifted from around $2310.5^{\circ} \mathrm{N}$ in period 1 to around $2^{\circ} \mathrm{N}$ in period 2 (Fig. $6 \mathrm{a}$ and $6 \mathrm{~b}$ ), thereby strongly increasing the 232 subsidence, or inhibiting the convection, between the equator and $3^{\circ} \mathrm{N}$, and increasing the 233 convection north of $4^{\circ} \mathrm{N}$ (Fig. 6c). The difference in time (period 2 minus period 1, or $\Delta$ ) 234 of the meridional SST gradient (dSST/dy) in Fig. 6d fits very well the pattern of $\Delta \mathrm{dZ} / \mathrm{dy}$ : 235 the largest value of $\mathrm{ldZ} / \mathrm{dyl}$ is indeed found between $1^{\circ} \mathrm{N}$ and $2^{\circ} \mathrm{N}$, slightly north of the $\Delta$ $236 \mathrm{dSST} / \mathrm{dy}$ maximum at $0.5^{\circ} \mathrm{N}-1^{\circ} \mathrm{N}$ : this is in agreement with a pressure anomaly forced by the 
237 SST front through the LN mechanism, which likely controls the strong northward acceleration 238 of southerlies between the equator and the coast. The impact of the SST front extends up to $239850 \mathrm{hPa}$ at $1^{\circ} \mathrm{N}$, which is even deeper than the boundary layer (which top is usually around $240900-950 \mathrm{hPa}$, not shown). Conversely, south of the front $\left(4^{\circ} \mathrm{S}-\mathrm{Eq}\right)$, the pressure gradient 241 slightly loosens, with a pattern matching the decrease in dSST/dy, which weakens down the 242 southerlies, but within a much shallower layer. The latter signal is in agreement with the LN 243 mechanism, but it also fits with the SW mechanism between $2^{\circ} \mathrm{S}$ and the equator, just over the 244 coldest part of the cold tongue, where only a thin surface layer (under $975 \mathrm{hPa}$ ) seems 245 influenced. As was previously found in the observations (de Coëtlogon et al. 2014), both 246 mechanisms appear indeed to control the surface wind in this area, with a time lag spanning 247 from a few hours (when the SW dominates) to 1 - 2 days (when the $\mathrm{LN}$ takes control).In 248 summary, the surface divergence induced by the SST front (seemingly through both SW and 249 LN mechanisms) around the equator creates a strong anomalous secondary circulation in the 250 low troposphere $(<700 \mathrm{hPa})$, subsiding at the equator and convecting at the coast, as well as a 251 strong deep subsidence over the NFCT. This is in very good agreement with the LLAC found 252 in ERA-interim and CFSR reanalyses, as described in Leduc-Leballeur et al. (2013): before 253 Tref, they found a large loop subsiding over the Gulf of Guinea south of $2^{\circ} \mathrm{S}$ and convecting 254 between the equator and the coast, with a northward monsoon flux near the surface and a 255 return southward branch around $700 \mathrm{mb}$. But after Tref, the LLAC is framed between the 256 equator and the coast, with its southern edge probably pushed north by the NFCT.

257 This seasonal shift of the LLAC in the Gulf of Guinea has a strong effect on precipitation, as 258 Fig. 5 already suggested. In addition, Fig. 7 presents the vertical cross-section of meridional259 vertical wind vectors and horizontal moisture flux divergence, highlighting the large control 260 of the latter on the precipitation profiles, averaged between $10^{\circ} \mathrm{W}$ and $0^{\circ} \mathrm{E}$. Before Tref, a 261 low-level divergent / convergent humidity flux pattern straddles the equator in the low 262 atmosphere $(<850 \mathrm{hPa})$. As suggested in Thorncroft et al. (2010), the SST between the 263 equator and $3^{\circ} \mathrm{N}$ is warmer than $28^{\circ} \mathrm{C}$ (see Fig. 3), which can trigger deep atmospheric 264 convection: the convergence maximum is located just south of $3^{\circ} \mathrm{N}$, framed by two divergent 
265 areas (south of the equator and north of $4^{\circ} \mathrm{N}$ ), in agreement with the diabatic heating 266 described for example in Gill (1981). After Tref, the SST cooling within the cold tongue leads

267 the southerlies strengthening north of the SST front (or NFCT) as discussed previously, hence 268 to the reinforcement of the divergent pattern and its northward shift by more than $200 \mathrm{~km}$, at 269 the equator. This likely leads the atmospheric subsident branch to migrate northward, up to $2702^{\circ} \mathrm{N}$, thereby reinforcing the moist convection inhibition (in addition to the SST cooling).

271 A strong reinforcement of the low-level moisture flux convergence is also visible between $2723^{\circ} \mathrm{N}$ and $5^{\circ} \mathrm{N}$ : it results from the wind strenghtening around $3^{\circ} \mathrm{N}$ on the one hand, and the 273 deceleration of the low-level wind as the air moves toward the Guinean coast at $4^{\circ} \mathrm{N}-5^{\circ} \mathrm{N}$ on 274 the other hand.

275 The latter probably comes from an increased coastal convergence, since the continental 276 surface friction considerably weakens the surface wind (and if the upstream wind is stronger, 277 then the deceleration due to the continental friction is larger as well, thereby increasing the 278 convergence). But in addition, there is also a clear positive $\mathrm{dZ} /$ dy signal that counters 279 southerlies north of about $3.5^{\circ} \mathrm{N}$ (Fig. 6c), with maximal values on the continental side of the 280 Guinean coast, of comparable magnitude than the ones created by the NFCT: clearly, this $281 \mathrm{dZ} / \mathrm{dy}$ inversion around $3.5^{\circ} \mathrm{N}$ is a major contributor of the low-level convergence between $2823^{\circ} \mathrm{N}$ and $5^{\circ} \mathrm{N}$ after Tref.

283 Very interestingly, the continental $\mathrm{dZ} / \mathrm{dy}$ maximal values, around $5.5^{\circ} \mathrm{N}$ and $6.5^{\circ} \mathrm{N}$, coincide 284 with huge negative peaks in the meridional gradient of SKT (Fig. 6, bottom). This suggests 285 that a flaw in the representation of the WRF wet continental conditions (or from the too286 abundant precipitation ?) may well explain the strong northerly bias in the model surface 287 wind north of $5^{\circ} \mathrm{N}$ after Tref, in comparison with satellite data, with a too-strong dZ/dy 288 inversion close to the Guinean coast.

289 Note that the patterns of the atmospheric mass divergence and of the humidity flux divergence 290 are very similar (not shown), which emphasizes the fact that the precipitation are strongly 291 controlled by the low-level atmospheric dynamics in this region. If thermodynamics are likely 
292 important before Tref for driving the deep atmospheric convection (precipitation oceanic

293 phase described in Thorncroft et al. 2010 and Nguyen et al. 2011), these results strongly

294 suggests that the NFCT apparition drives the increased coastal convergence and the Guinean

295 coastal rainfall after Tref.

\section{4. Quantitative estimations of the SST influence on surface wind}

298 In order to compare the simulation with observations more easily, we attempt here to quantify 299 the impact of the SST and dSST/dy on the surface wind speed where their influence is 300 maximal: the cold tongue for SST, and its northern front for dSST/dy.

301 Surface wind speed, SST and dSST/dy were zonally averaged between $10^{\circ} \mathrm{W}$ and $0^{\circ} \mathrm{E}$, in 302 three different latitude bands: $1^{\circ} \mathrm{S}-\mathrm{Eq}\left(\mathrm{SST}+\right.$ wind speed), Eq- $1^{\circ} \mathrm{N}(\mathrm{dSST} / \mathrm{dy})$, and $2.5^{\circ} \mathrm{N}-$ $3033.5^{\circ} \mathrm{N}$ (wind speed). This leads to 61 daily values around Tref (i.e. from Tref -30 days until 304 Tref +30 days), from the 2-months WRF simulation, or from the composites computed with 305 observations and CFSR reanalysis.

306 A linear regression was performed on the surface wind speed versus SST in the $\left[1^{\circ} \mathrm{S}-\mathrm{Eq}\right]$ 307 band, allowing to estimate the amplitude of the local wind response to the small-scale SST 308 features within a few hours through the SW mechanism (Fig. 8, left). Note that before Tref, 309 the equatorial SST is rather uniformly warm: the equatorial wind is then mostly driven by the 310 large-scale atmospheric circulation. Only post-Tref values were therefore taken into account 311 for the linear regression fits (i.e. days plotted with dots in Fig. 8, left, whereas circles 312 represent the days before Tref). In the observations, the SST / wind speed fit has a slope of 313 almost $1 \mathrm{~m} / \mathrm{s} / \mathrm{K}$, which indicates a cooling of the SST by about $1 \mathrm{~K}$ inducing a weaker wind 314 speed by more than $1 \mathrm{~m} / \mathrm{s}$ (blue line). De Coëtlogon et al. (2014) found that both ERA-Interim 315 and CFSR tend to underestimate the wind response to the SST fluctuations at intraseasonal 316 timescales, which is also found here at the seasonal scale with a slope of less than $1 / 2 \mathrm{~m} / \mathrm{s} / \mathrm{K}$ 317 for CFSR (green line). On the contrary, the WRF model exhibits a decreased wind when the 
318 SST has cooled down with a slope slightly larger than $1 \mathrm{~m} / \mathrm{s} / \mathrm{K}$, which broadly fits the 319 observations pending uncertainties (red line).

320 The surface wind response to dSST/dy through the LN mechanism was similarly estimated,

321 but in taking into account the delayed response in time (1-2 days) and space (advection by the 322 mean atmospheric flow, Fig. 8, right): dSST/dy is then averaged in [Eq- $\left.1^{\circ} \mathrm{N}\right]$, and the wind 323 response is measured by substracting the wind speed just south of the front (at $\left.\left[1^{\circ} \mathrm{S}-\mathrm{Eq}\right]\right)$ from 324 the wind speed further north $\left(\right.$ at $\left.\left[2.5^{\circ} \mathrm{N}-3.5^{\circ}\right]\right)$, thereby isolating the wind strenghtening due to 325 the SST gradient from the large-scale atmospheric circulation.

326 The regression fit matches very well the observations, with a slope of 4 to $5 \mathrm{~m}$.(lat. deg.)/s/K 327 (Fig. 8 right, simulation in red and observations in blue), whereas the CFSR reanalysis clearly 328 appears to underestimate the mechanism amplitude (green line). This suggests that the wind 329 strenghtening when crossing the NFCT (due to the LN mechanism) in the model is in good 330 agreement with the observations. Note that the set of WRF parameterizations were carefully 331 chosen in order to get the characteristic weak / strong seasonal wind pattern on each side of 332 the NFCT (Meynadier et al. 2014), but this did not guarantee to get realistic linear amplitudes 333 of the wind response to both LN and SW forcing mechanisms.

334 The surface wind is usually considered as resulting from a balance between the pressure 335 gradient force, the Coriolis force, and the friction forces (drag at the surface, and momentum 336 entrainment from the wind shear above), usually neglecting the advection (inertial) term, as in 337 the simple model of Stevens et al. (2002). The SST influences the wind through a local 338 modification of the pressure gradient (LN mechanism), opposing the large-scale pressure 339 gradient - rather controlled by the free troposphere above the MABL. In addition, through the 340 SW mechanism and the stratification in the MABL, the SST partly controls the momentum 341 entrainment from above. Therefore, a flaw in the representation of the atmospheric circulation 342 in the free troposphere, above the MABL top - where the vertical gradients, such as humidity 343 gradient are very strong (Meynadier et al 2014), - could have a large impact on the surface 344 wind representation. Eventually, we found that the horizontal advection (inertial) term 
$345 \vec{U} \cdot \nabla \vec{U}$ is also very important for this region in the WRF simulation. Fig. 9 shows its

346 mean value during the 2-month simulation: it can amount to as much as half of the pressure

347 gradient magnitude $\frac{1}{\rho}\|\nabla S L P\|$, as shown in Fig. 9. In particular, this ratio is of about $34835 \%$ around $3^{\circ} \mathrm{N}$ between $10^{\circ} \mathrm{W}$ and $0^{\circ} \mathrm{E}$ on average in the 2-month simulation, with a larger 349 value (up to $50 \%$ ) if period 2 only is considered, because the wind is stronger (not shown).

350 The advection is therefore actually far from being negligible in the Eastern Equatorial

351 Atlantic, compared to SST or free troposphere influences, which would probably reinforce 352 any bias induced by the representation of these 2 terms.

353 In short, the SST influence on the surface wind appears to match well the observations in 354 agreement with the SW and LN mechanisms amplitudes. But quite strong biases remain in the 355 surface wind model compared to the observations, which questions the influence of larger356 scale environmental factors, such as the free tropospheric circulation or the continental 357 surface. In particular, the next section investigates if the characteristic wind pattern evolution 358 around Tref is actually due to the cold tongue development in the SST, or rather to a remote 359 forcing.

\section{5. Sensitivity cross-experiments : SST vs external forcing}

362 In order to test if the results of previous sections are really due to the change in SST, and not 363 to the change in the forcing parameters at the model boundaries, four additional WRF 364 simulations were performed. All were made with a stationary external forcing, averaged either 365 in period 1 (before Tref) or in period 2 (after Tref), with a permanent diurnal cycle (the same 366 composite day of period 1 was repeated during 8 weeks, and the same was done for the 367 composite day of period 2):

368 * external forcing of period 1 with the SST of period 1 (thereafter "case1")

369 * external forcing of period 2 with the SST of period 2 (thereafter "case2"), 
$370 *$ external forcing of period 1 with the SST of period 2 (thereafter “case1_SST2”),

$371 *$ external forcing of period 2 with the SST of period 1 (thereafter "case2_SST1").

372 This way, the influence of the SST change can be tested in the conditions of constant period 1

373 or constant period 2, i.e. without any change in the external forcing (case1_SST2 minus

374 case1, or case2 minus case2_SST1), whereas the influence of the external forcing can be

375 tested in the conditions of a constant SST (case2_SST1 minus case1, or case2 minus

376 case1_SST2). Indeed these effects are certainly not completely linear, and the method misses

377 their non-linear dynamics, but some of their main characteristics can nonetheless be depicted.

378 The significance of these differences were validated by a t-test, based on rms estimated for

379 case 1 and case 2 simulations, the maximal value between the 2 being kept at each grid point.

380 One degree of freedom per day was taken (which correspond to an exponential decrease of

381 less than one day in autocorrelations, checked for a few SLP and meridional surface wind

382 gridpoints, not shown). The null hypothesis (i.e. non significant difference between the 2

383 values) was only rejected when the difference exceeded the $95 \%$ t-value, thereby taking into

384 account the large level of noise in the simulations due to internal variability in the model.

385 Fig. 10 shows the difference in SLP patterns due to a change in SST (top row) or in the

386 external forcing (bottom row). The seasonal evolution of the SLP is clearly due to the SST

387 change, since the maximal SLP fluctuations (1 to $1.5 \mathrm{mb}$ ) are located close to the minimal

388 SST ones for both periods (about $-2 \mathrm{~K}$, as shown in black contours). In the simulations only

389 differing by the external forcing (the SST is the same), the SLP does not increase

390 significantly in the equatorial region (bottom row), by less than $0.3-0.4 \mathrm{mb}$. Only the

391 southern Eastern Equatorial Atlantic (south of $5^{\circ} \mathrm{S}$ ) appears significantly influenced by the

392 external forcing.

393 The impact of the SST vs the external forcing is also shown in Fig. 11: there again, the 394 northward wind acceleration between the equator and the coast appears very clearly due to the 395 SST change. Shadings indicate the change in the meridional SLP gradient (thereafter 
$396 \mathrm{dSLP} / \mathrm{dy}$ ): the northward wind acceleration can clearly be attributed to a larger than normal 397 SLP gradient (in magnitude) toward the continent, with a maximum in the NFCT area 398 around $0.5^{\circ} \mathrm{N}-1^{\circ} \mathrm{N}$ (Fig. 11, top row), thereby illustrating the LN mechanism previously 399 described. Note that the IdSLP/dyl maximum is located slightly north of the NFCT, and the 400 wind acceleration maximum even further north (between $3^{\circ} \mathrm{N}$ and $4^{\circ} \mathrm{N}$ ), likely because of an 401 important advection by the mean flow as discussed previously.

402 South of the NFCT, and as expected from this side of the front (where dSST/dY <0), the 403 weaker IdSLP/dYI (by about $0.05 \mathrm{mb}$ per lat. deg.) induces a generally weaker wind south of 404 the equator, by up to $1 \mathrm{~m} / \mathrm{s}$ (Fig. 11, top row). Moreover, the general strengthening of the 405 external boundary wind forcing, from period 1 to period 2, generates opposite (stronger) wind 406 anomalies of smaller magnitude (Fig. 11, bottom row). Note that these two different forcings 407 result into a rather modest weakening of the wind south of the equator, from period 1 to 408 period 2, in the WRF composite simulation discussed in previous sections (as seen for 409 example in Fig. 4, middle right), which would interestingly suggest that the seasonal 410 reinforcement of the Trade winds in the southeastern Tropical Atlantic by the northward 411 migration of the InterTropical Convergence Zone can be largely damped as far south as $7^{\circ} \mathrm{S}$ 412 by the cold tongue development.

413 Cross-test experiments were also investigated vertically: they show that the NFCT impact is 414 very strong around the equator, and significant from as far south as $6^{\circ} \mathrm{S}$, up to the coast at $5^{\circ} \mathrm{N}$ 415 (not shown). However, the strong signals seen over the continent in Fig. 6 and 7 (north of $4165^{\circ} \mathrm{N}$ ) appear due to the seasonal change of the external forcing (surface conditions ?), and 417 probably to the Saharan Heat Low reinforcement as well in period 2 (not shown).

418 Cross-test experiments were then analyzed regarding the water cycle components. Figure $12 \mathrm{~b}$ 419 clearly shows that with the set-up of the NFCT, the SST seasonal evolution solely pushes 420 precipitation toward the Guinean coast and suppresses moist convection south of $4^{\circ} \mathrm{N}$. 421 Precipitation patterns are spatially well correlated with vertically integrated moisture flux 422 anomalies (figure $12 \mathrm{a}$ and $\mathrm{b}$ ). In term of spatial structures and amplitude, the change of 
423 moisture flux convergence (or divergence) due to the change of SST exhibits indeed a very

424 consistent pattern with the rainfall changes. Note that the vertically integrated moisture flux

425 field (represented by vectors in Figure 12a) is very close to the surface wind pattern due to

$426 \mathrm{dSLP} / \mathrm{dy}$ : change before and after Tref in moisture flux convergence or divergence (and then

427 precipitation) is directly connected to the low-level wind changes due to the SST seasonal

428 evolution. The vertical structure of moisture convergence (Figure 12c) confirms the influence

429 of the SST changes over the ocean, even if the amplitude of the low level moisture divergence

430 and the associated suppressed rain (between the equator and $3^{\circ} \mathrm{N}$ ) is likely overestimated,

431 compared to Fig. 7 (right panel). An explanation of this could be that the simulation with

432 everyday similar warm SST forcing before Tref leads to large amount of ocean precipitation

433 using the BMJ cumulus scheme.

\section{6. Conclusion}

436 The air-sea interaction mechanisms in the Gulf of Guinea and their role in the coastal 437 precipitation are investigated from WRF experimental simulations. It is shown here that the

438 WRF simulation captures very well the seasonal transition of the rainfall from an oceanic 439 phase to the Guinean coastal one, as well as the transition of the surface wind speed from a 440 rather uniform distribution in the gulf of Guinea to a very characteristic pattern across the

441 NFCT (weak around the equator, strong further north). The increased low-level convergence 442 near the coast has for effect to set the Guinean coastal rainfall described in Nguyen et al. 443 (2011). Boundary and lateral forcing cross-test experiments made with WRF clearly show 444 that the SST seasonal evolution solely pushes precipitation toward the Guinean coast and 445 suppresses moist convection south of $4^{\circ} \mathrm{N}$. This is due to a change in moisture flux 446 convergence directly connected to the low-level wind changes under the influence of the SST 447 seasonal variability.

448 The amplitude of the seasonal cold tongue impact on surface wind through the SW 449 mechanism is estimated with linear regression, leading to a value of about $1 \mathrm{~m} / \mathrm{s} / \mathrm{K}$, in 
450 agreement with the estimations made at intraseasonal timescales in de Coëtlogon et al. 451 (2014). It is about twice as large as the SST impact on the overlying wind speed as measured 452 in extratropical regions (Perlin et al. 2014, Small 2008). In addition, through the LN 453 mechanism, the NFCT accelerates the surface wind by 4 to $5 \mathrm{~m}$.(lat. deg.)/s/K. These values 454 compare very well with the ones found in the observations, whereas the CFSR reanalysis 455 exhibits a clear tendency to underestimate the impact of both mechanisms, which is consistent 456 with the northerly surface wind bias found between the equator and the coast in the reanalysis 457 and may be partly due to a lower resolution (de Coëtlogon et al., 2014). However, putting 458 aside the hypothesis that observations could be wrong there (since the QuikSCAT product is 459 known to be taken with great cautions in the $100-\mathrm{km}$ band off the coasts, as all scatterometers 460 products), a similar strong northerly wind bias is also found in the WRF simulation in the 461 northern Gulf of Guinea. As discussed in section 3c, the latter is likely linked to a strong 462 decrease in the meridional gradient of the low-level pressure near the Guinean coast in the 463 WRF simulation after Tref (Fig. 6c), which would excessively weaken down the upstream 464 marine southerlies north of $3.5^{\circ} \mathrm{N}$. This large change in the meridional pressure gradient 465 seems to be of inland origin, which could suggest a flaw in the model representation of the 466 continental response to excessive coastal convergence and convection in the Guinean coastal 467 region in the model. This flaw could also explain why the secondary circulation between the 468 equator and the coast, or LLAC, after Tref, appears to be weaker in the model than in the 469 reanalyses (ERA interim as well as CFSR), since this cell variability is probably driven not 470 only by the surface pressure gradients but also by internal thermodynamics (it would indeed 471 be partly driven by the humidity convergence at the coast, see Leduc-Leballeur et al. 2013 or 472 de Coëtlogon et al. 2014). Eventually, it is important to keep in mind that the advection of 473 momentum by the mean atmospheric flow plays a very significant role in the cold tongue 474 region.

475 Unhappily, too few observations of the low troposphere are available in this region to 476 properly document the LLAC, whith only a few radiosoundings launched from the AMMA 4772006 (EGEE) and PIRATA 2014 campaigns. Further investigations and a better 478 documentation of the low troposphere dynamics in the northern Gulf of Guinea are therefore 
479 strongly needed regarding the structure of the LLAC, especially after Tref, since its 480 misrepresentation could be a clue in the general difficulty of the models to correctly represent 481 the West African Monsoon later on in the season (by, for example, advecting not enough 482 moisture from the Gulf). 
484 Caniaux G, Giordani H, Redelsperger J-L, Guichard F, Key E, Wade M. 2011. Coupling 485 between the Atlantic cold tongue and the West African monsoon in boreal spring and summer. 486 J. Geophys. Res. 116: C04003, DOI: 10.1029/2010JC006570.Cook, K.H., 2015 : Role of 487 inertial instability in the West African monsoon jump. J. Geophys. Res., 488 10.1002/2014JD022579

489 De Coëtlogon, G., S. Janico et A. Lazar, 2010 : Intraseasonal variability of the ocean490 atmosphere coupling in the Gulf of Guinea during boreal spring and summer. Quart. J. Roy. 491 Meteor. Soc., 136, S1, 426-441.

492 De Coëtlogon, G., and co-authors, 2014: Atmospheric response to sea surface temperature in 493 the Eastern Equatorial Atlantic at quasi-biweekly timescales. Quart. J. Roy. Meteor. Soc., 494 140: 1700-1714. doi: 10.1002/qj.2250.

495 Flaounas, E., S. Janicot, S. Bastin, and R. Roca (2012), The West African monsoon onset in 496 2006: Sensitivity to surface albedo, orography, SST and synoptic dry-air intrusions using 497 WRF, Clim. Dyn., 38, 685-708.

498 Giordani, H., G. Caniaux, and A. Voldoire, 2013 : Intraseasonal mixed layer heat budget in 499 the equatorial Atlantic during the cold tongue development in 2006. J. Geophys. Res., 500 doi : $10.1029 / 2012 \mathrm{JC} 008280,118,650-671$.

501 Hayes SP, McPhaden MJ, Wallace JM. 1989. The in uence of sea-surface temperature on 502 surface wind in the eastern equatorial Paci c: Weekly to monthly variability. J. Climate 2: $503 \quad 1500-1506$.

504 Huffman GJ, Adler RF, Bolvin DT, Gu G, Nelkin EJ, Bowman KP, Hong Y, Stocker EF and 505 Wolff DB., 2007: The TRMM Multisatellite Precipitation Analysis (TMPA): Quasi-global, 506 multiyear, combined-sensor precipitation estimates at ne scales. J. Hydrometeorol. 8: 38-55. 507 Jouanno J., F. Marin, Y.du Penhoat, and J.M Molines, 2013: Intraseasonal Modulation of the 508 Surface Cooling in the Gulf of Guinea. J. Phys. Oceanogr., 43, 382-401. 
509 Lavaysse C, Flamant C, Janicot S, Parker D, Lafore JP, Sultan B, Pelon J (2009) Seasonal 510 cycle of the West African heat low: a climatological perspective. Clim Dyn. 511 doi:10.1007/s00382-009-0553-4

512 Leduc-Leballeur, M., L. Eymard et G. De Coëtlogon, 2011 : Observation of the marine 513 atmospheric boundary layer in the Gulf of Guinea during the 2006 boreal spring. Quart. J. 514 Roy. Meteor.Soc., 137, 657, 992-1003.

515 Leduc-Leballeur, M., G. De Coëtlogon, et L. Eymard, 2013 : Air-sea interaction in the gulf of 516 Guinea at intraseasonal time-scales : wind bursts and coastal precipitation in boreal spring. 517 Quart.J.Roy. Meteor.Soc., 139, 671, 387-400.

518 Lindzen R. S. and Nigam S. 1987. On the role of sea surface temperature gradients in forcing 519 low-level winds and convergence in the tropics. J. Atmos. Sci., 44(17) : 2418-2436.

520 Liu WT, Xie X, Polito PS, Xie S-P, Hashizume H. 2000. Atmospheric manifestation of 521 tropical instability wave observed by QuikSCAT and Tropical Rain Measuring Mission. 522 Geophys. Res. Lett. 27: 2545-2548.

523 Marin F., Caniaux G., Bourles B.,Giordani H., GouriouY., Key E. 2009. Why were sea surface 524 temperatures so different in the eastern equatorial Atlantic in June 2005 and 2006? J. Phys. 525 Oceanogr.39: 1416-1431.

526 Meynadier R., G. de Coetlogon, S. Bastin, L. Eymard, S. Janicot, 2014. Sensitivity testing of 527 WRF parametrizations on air-sea interaction and its impact on water cycle in the gulf of 528 Guinea, Quarterly Journal of the Royal Meteorological Society, DOI :10.1002/qj.2483.

529 Nguyen, H., C. D. Thorncroft, and C. Zhang (2011), Guinean coast rainfall of the West 530 African monsoon, Q. J. R. Meteorol. Soc., 137, 1828-1840.

531 Perlin, N., S ; P. de Szoeke, D ; B. Chelton, R. M. Samelson, E. D. Skyllingstad and L. W. 532 O’Neill, 2014: Modeling the Atmospheric Boundary Layer Wind Response to Mesoscale Sea 533 Surface Temperature Perturbations. Mon. Wea. Rev., 142, 4284-4307. doi: 534 http://dx.doi.org/10.1175/MWR-D-13-00332.1. 
535 Reynolds RW, Smith TM, Liu C, Chelton DB, Caset KS, Schlax MG. 2007. Daily high-

536 resolution blended analyses for sea surface temperature. J. Clim. 20: 5473-5496.

537 Saha S, Moorthi S, Pan H, Wu X, Wang J, Nadiga S, Tripp P, Kistler R, Woollen J, Behringer

538 D, Liu H, Stokes D, Grumbine R, Gayno G, Wang J, Hou Y, Chuang H, Juang H, Sela J, 539 Iredell M, Treadon R, Kleist D, Van Delst P, Keyser D, Derber J, Ek M, Meng J, Wei H, Yang 540 R, Lord S, van den Dool H, Kumar A, Wang W, Long C, Chelliah M, Xue Y, Huang B, 541 Schemm J, Ebisuzaki W, Lin R, Xie P, Chen M, Zhou S, Higgins W, Zou C, Liu Q, Chen Y, 542 Han Y, Cucurull L, Reynolds R, Rutledge G, Goldberg M. 2010b. Supplement to The NCEP 543 Climate Forecast System Reanalysis. Bull. Am. Meteorol. Soc., 91,1015-1057.

544 Skamarock WC, Klemp JB, Dudhia J, Gill DO, Barker DM, Duda MG, Huang XY, Wang W, 545 Powers JG. 2008. 'A description of the advanced research WRF version 3'. NCAR Technical 546 Note-475+STR. NCAR: Boulder, CO. http://www.mmm.ucar.edu/wrf/users/docs/arw v3.pdf 547 (accessed 20 October 2014).

548 Small R.J., de Szoeke SP, Xie SP, O’Neill L, Seo H, Song Q, Cornillon P, Spall M, Minobe S. 549 2008. Air sea interaction over ocean fronts and eddies. Dynam. Atmos. Oceans 45: 274-319.

550 Sweet W., Fett R., Kerling J. et La Violette P. 1981. Air-Sea Interaction Effects in the Lower 551 Troposphere Across the North Wall of the Gulf Stream. Mon. Wea.Rev., 109(5) : 1042-1052.

552 Thorncroft, C. D., H. Nguyen, C. Zhang, and P. Payrille (2011), Annual cycle of the West 553 African monsoon: Regional circulations and associated water vapour transport, Q. J. R. 554 Meteorol. Soc., 137, 129-147.

555 Wallace J. M., Mitchell T. P. et Deser C. 1989. The influence of sea-surface temperature on 556 surface wind in the eastern equatorial Pacific : seasonal and interannual variability. J. Clim., 557 2(12): 1492-1499.

558 Yin, B. and B. A. Albrecht, 2000: Spatial Variability of Atmospheric Boundary Layer 559 Structure over the Eastern Equatorial Pacific. J. Climate, 13, 1574-1592. 
2000:

2001:

$05 / 26$

2002:

$05 / 29$

ere

nce

dat

2003:

06/04

es

2004:

06/06

Tre

$\mathrm{f}$

for

2005:

05/11

eac

$\mathrm{h}$

2006:

$06 / 25$

par

tic

2007:

06/01

ula

$\mathrm{r}$

2008:

06/01

yea

$r$,

2009:

06/02

fro

$\mathrm{m}$

2000 to 2009 (black star), with 《 period $1 \gg$ (from [Tref - 3 weeks] until [Tref - 1 week], blue line) and 《 period $2 》$ (from Tref until [Tref +2 weeks], red line). 


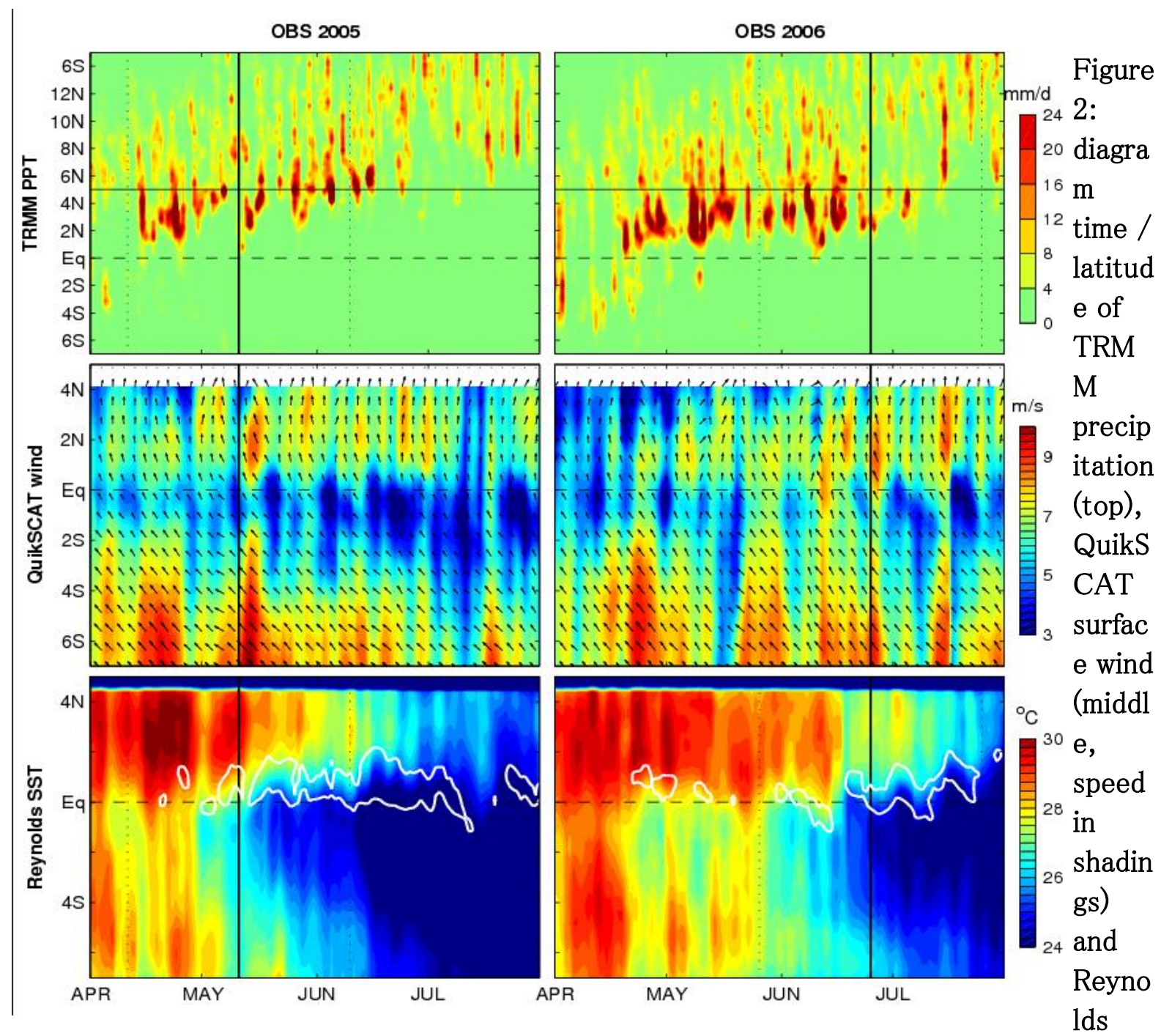

SST (bottom), $10^{\circ} \mathrm{W}-0$, in May-June-July-August 2005 (left) and 2006 (right). White contour in the lower row indicates a SST meridional gradient of $0.6 \mathrm{~K}$ per latitude degree. Vertical black line points Tref, and black dotted lines frame a period of 2 months around Tref. 


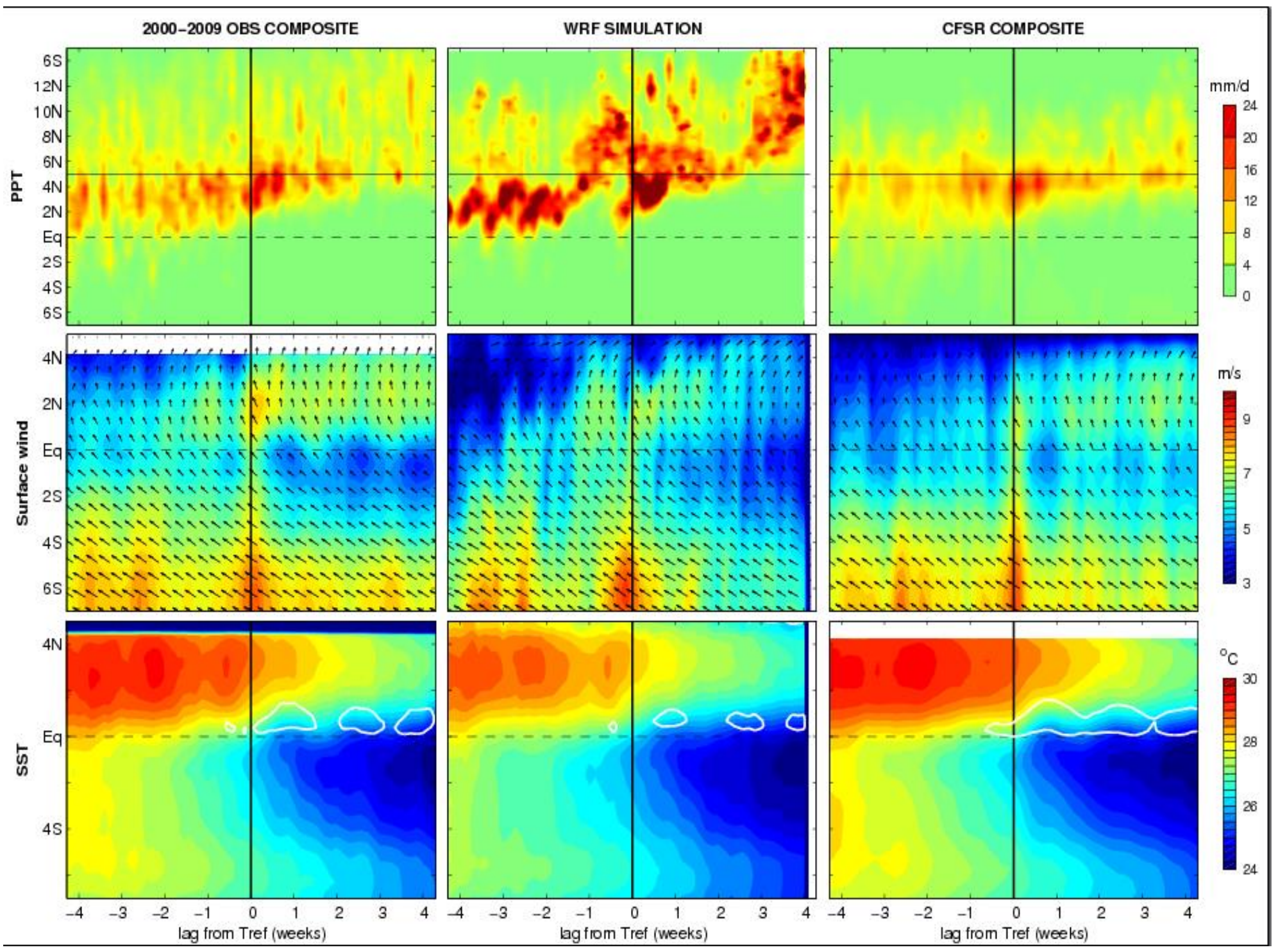

Figure 3: time / latitude diagrams of ${ }^{\sim} 2$-month composites around the date of reference Tref, $10^{\circ} \mathrm{W}-0$ : in the observations (left column), in the WRF simulation (middle), and in the CFSR ranalysis (right) ; of PPT (top row), surface wind (middle) and SST (bottom, SKT for WRF). Black vertical lines indicate Tref. White contours in lower frames indicate level $0.6 \mathrm{~K}$ per latitude-degree for the SST (OBS and CFSR) or SKT (WRF output) meridional gradient. 

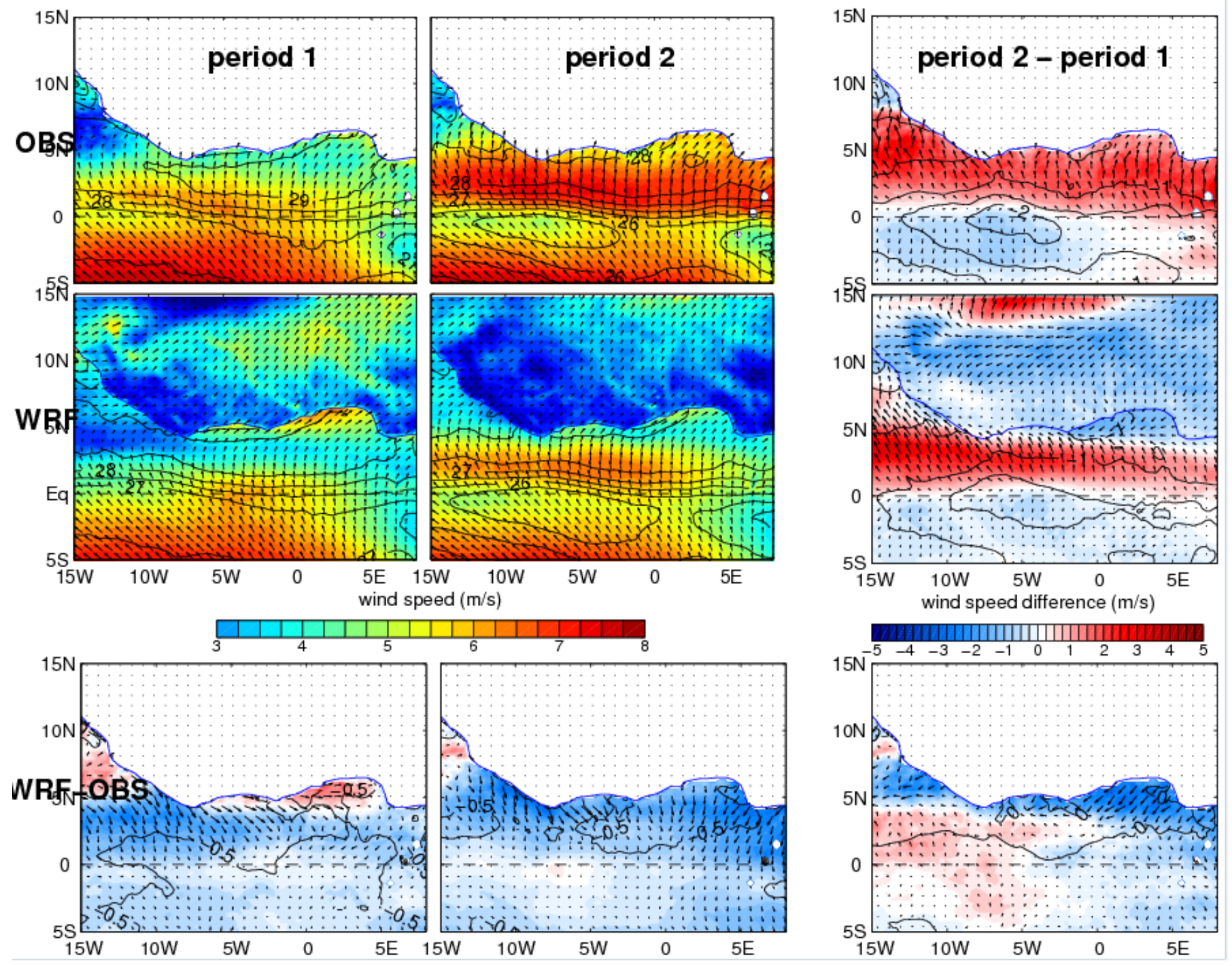

Figure 4: Top row: observed QuikSCAT surface wind velocity (speed in shadings, $\mathrm{m} / \mathrm{s}$ ) and Reynolds SST (black contours), averaged in Period 1 (i.e. from Tref- 3 weeks to Tref -1 week, left), Period 2 (average from Tref to Tref +2 weeks, middle column), and their difference (right). Middle row: similar than top row, but for the WRF simulation with SKT instead of SST (SKT not plotted over the continent for clarity). Bottom row: differences between top and middle rows (WRF-OBS). 

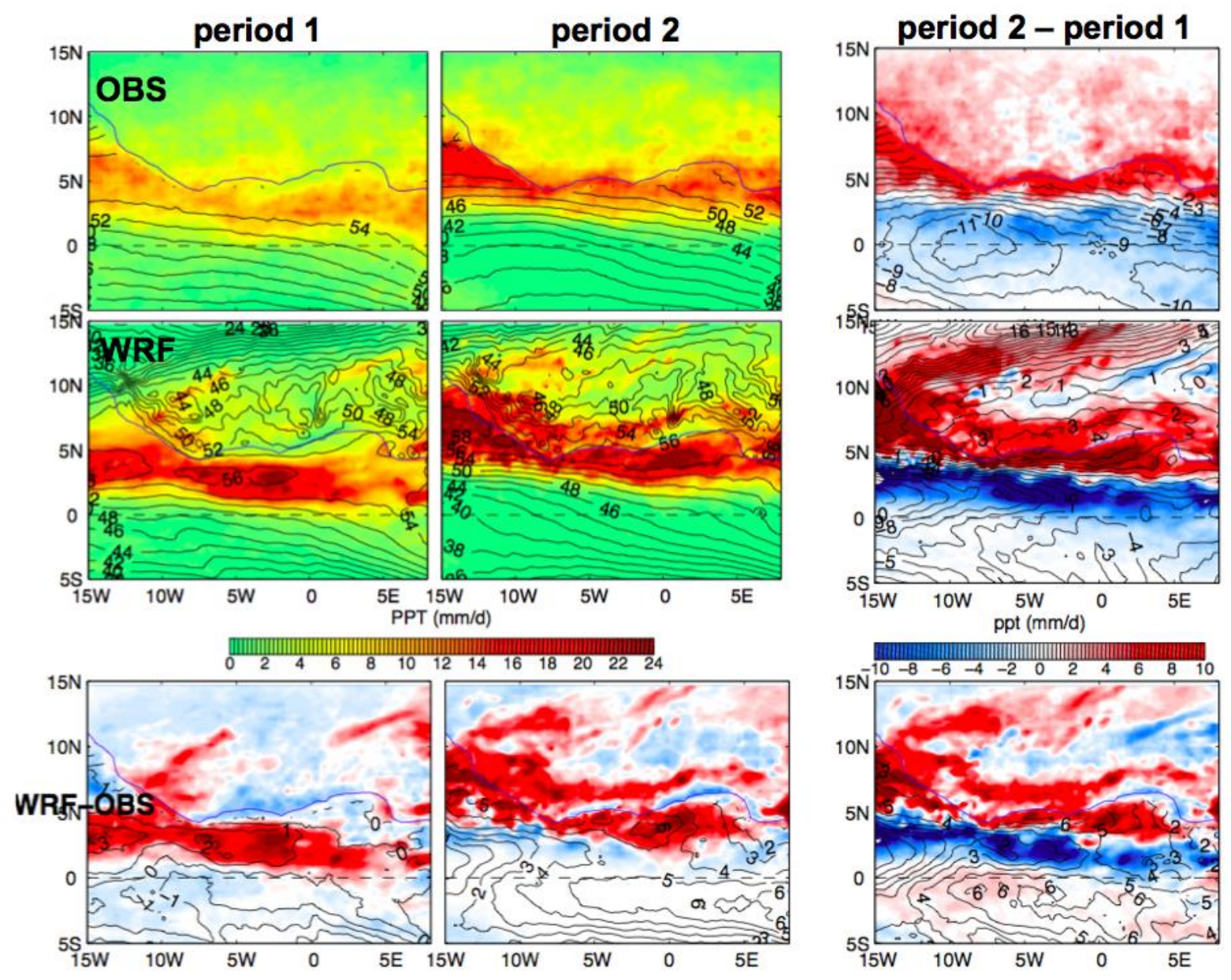

Figure 5: similar than Fig. 4, but for precipitation (shadings, in $\mathrm{mm} /$ day, observations from the TRMM B42 product) and precipitable water vapor (black contours, intervals of $2 \mathrm{~kg} / \mathrm{m} 2$ ). 


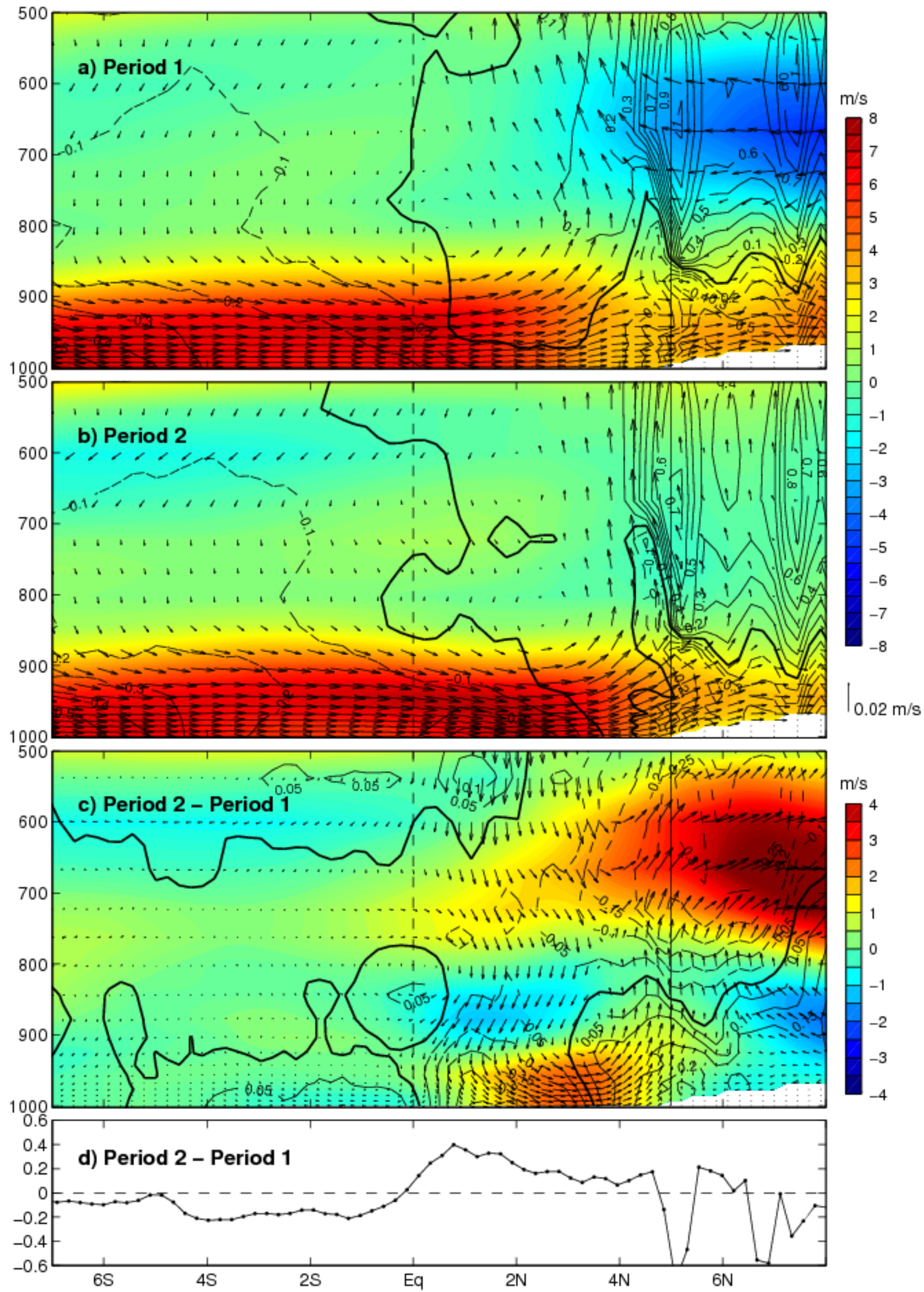

Figure 6: $10^{\circ} \mathrm{W}-0$, WRF simulation composites 《Period $1 》(\mathrm{a}), 《$ Period $2 》(\mathrm{~b})$ and $《$ Period $2 \gg$ minus $《$ Period $1 \gg(\mathrm{c})$ of meridional wind (shadings) and meridional gradient of geopotential height (black contours, intervals of $0.1 \mathrm{~m}$ per lat. degree for a and b, or $0.05 \mathrm{~m}$ per lat. degree for $\mathrm{c}$, level 0 in heavy black). (d): 《Period $2 》 \operatorname{minus} 《$ Period $1 》$ of the meridional gradient of SKT (K per lat. deg.). Vertical dashed line stands fo the equator latitude, plain for the Guinean 
coast mean latitude $\left(5^{\circ} \mathrm{N}\right)$. 

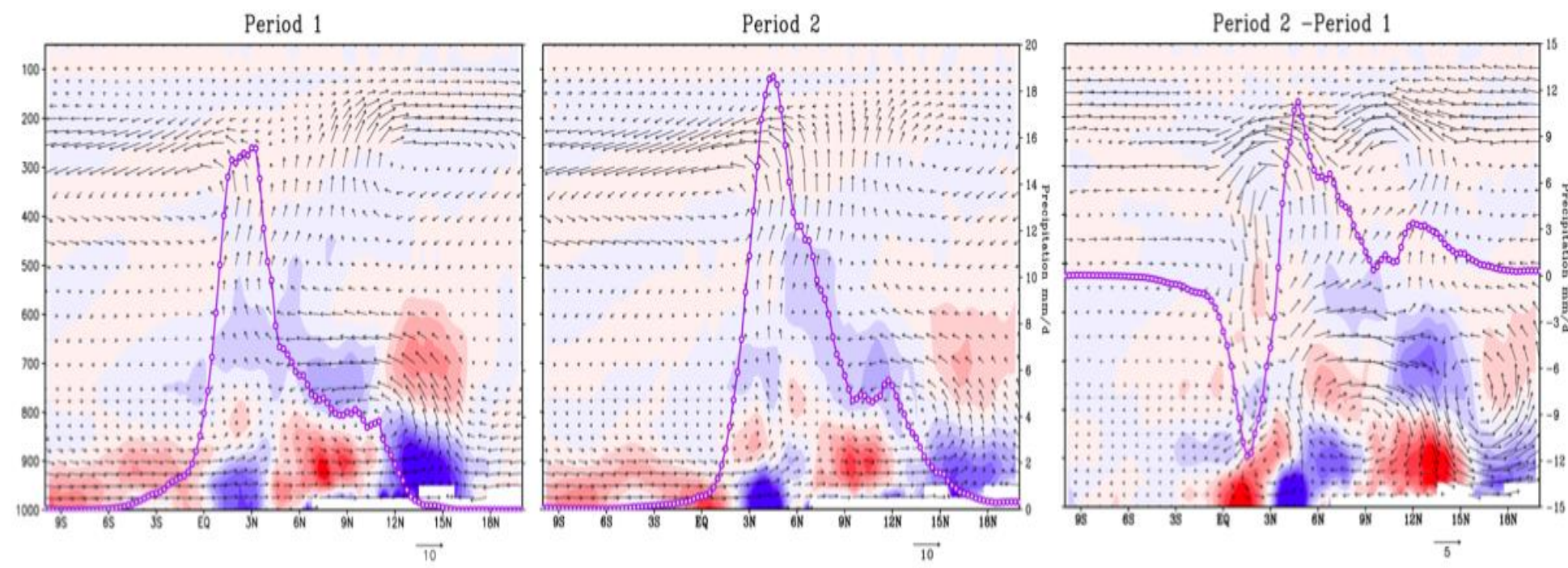

Figure 7: $10^{\circ} \mathrm{W}-0 \mathrm{WRF}$ simulation averages in period 1 (left), period 2 (middle) and their difference (right), of the meridional humidity divergence (shadings, $\mathrm{kg} / \mathrm{m} 3 / \mathrm{s}$ ), the meridional circulation (arrows) and the precipitation (magenta profile, $\mathrm{mm} /$ day). 

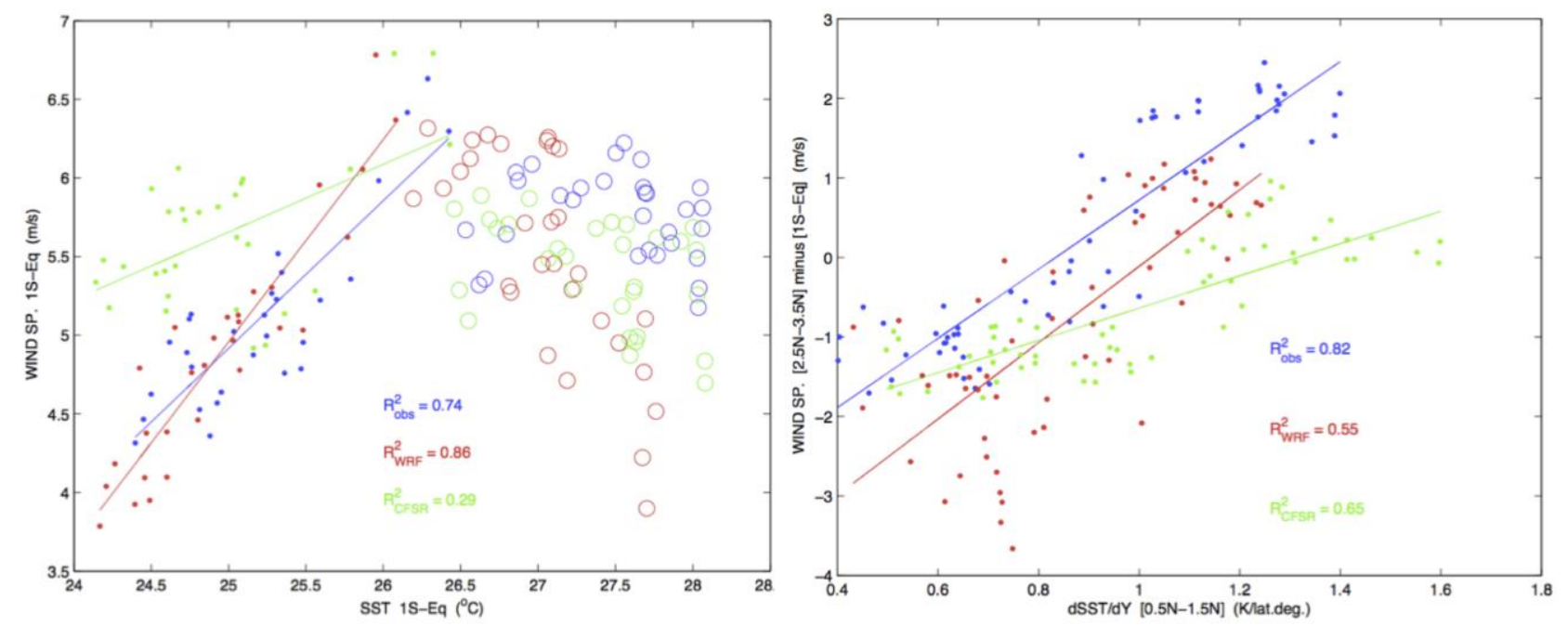

Figure 8: Left: composites of daily surface wind speed versus daily SST, 2000-2009, 10 $\mathrm{W}-0$ / $1^{\circ} \mathrm{S}-\mathrm{Eq}, 30$ days before (circles) and 30 days after (dots) Tref, in the observations (blue) and CFSR reanalyses (green), or in the corresponding WRF simulation (red). Lines : linear 《least square fit $\gg$ regressions. Right: similar, but for the surface wind speed difference $\left(\left[2.5^{\circ} \mathrm{N}-\right.\right.$

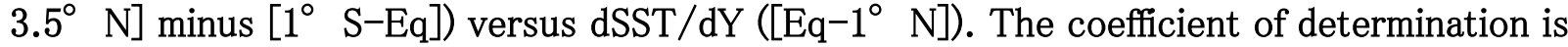
indicated for each regression. 


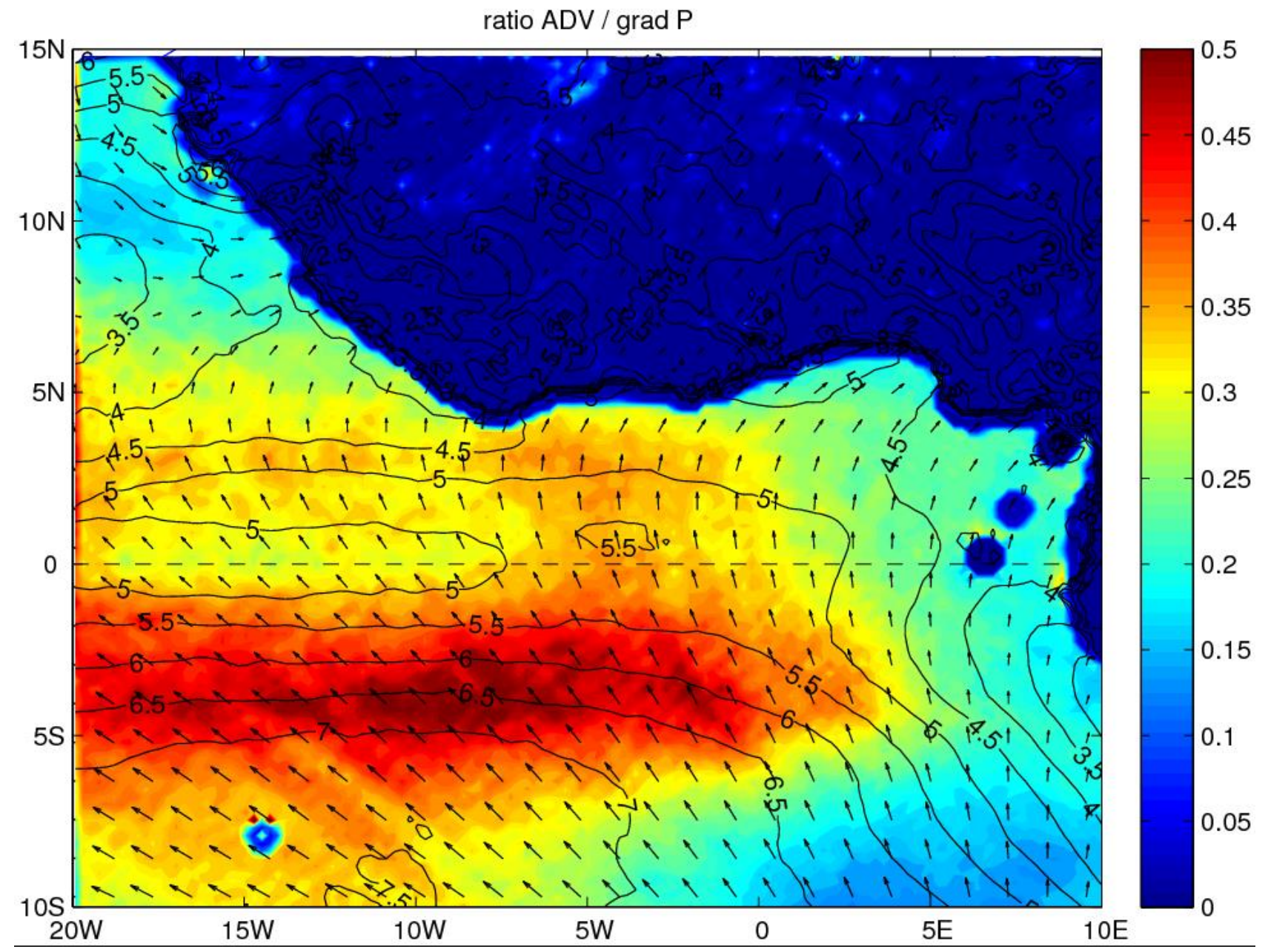

Figure 9: In the WRF simulation, fraction of the advection (inertial) term $\|U . \nabla U\|$, versus the pressure gradient term $\frac{1}{\square}\|\nabla S L P\|_{\text {where }} \square=1.12 \mathrm{~kg} / \mathrm{m}^{3}$ (shading). Mean $\mathbb{U}$ (arrows) and wind speed $\|U\|$ (black contours, intervals of $0.5 \mathrm{~m} / \mathrm{s}$ ). All terms were first computed at the simulation output frequency (i.e. 8 values per day during the 2-month simulation around Tref), and then averaged over the whole period. 
SLP(case 1_SST2) - SLP(case 1)

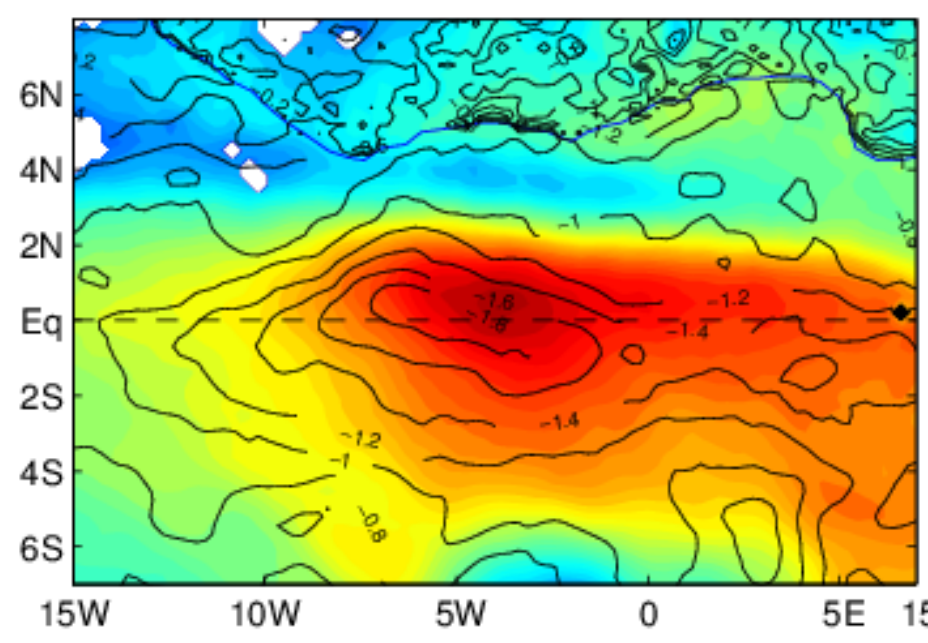

SLP(case 2) - SLP(case 1_SST2)

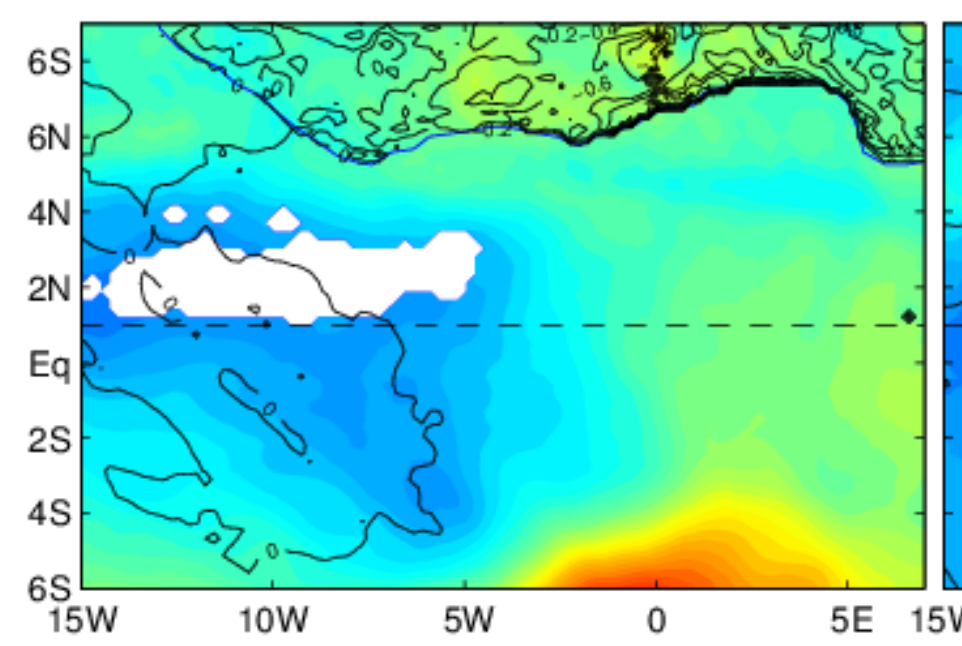

SLP(case 2)- SLP(case 2_SST1)

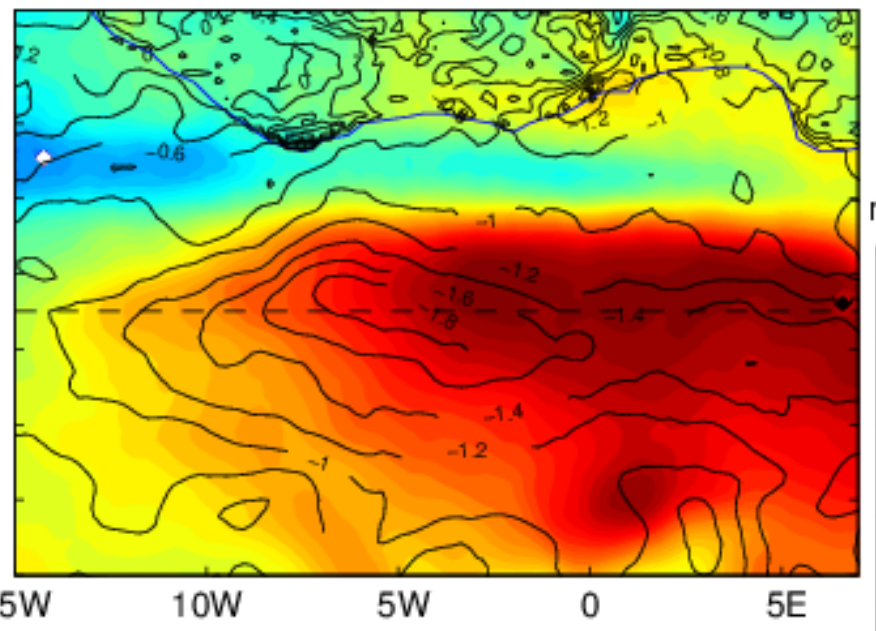

SLP(case 2_SST1) - SLP(case 1)

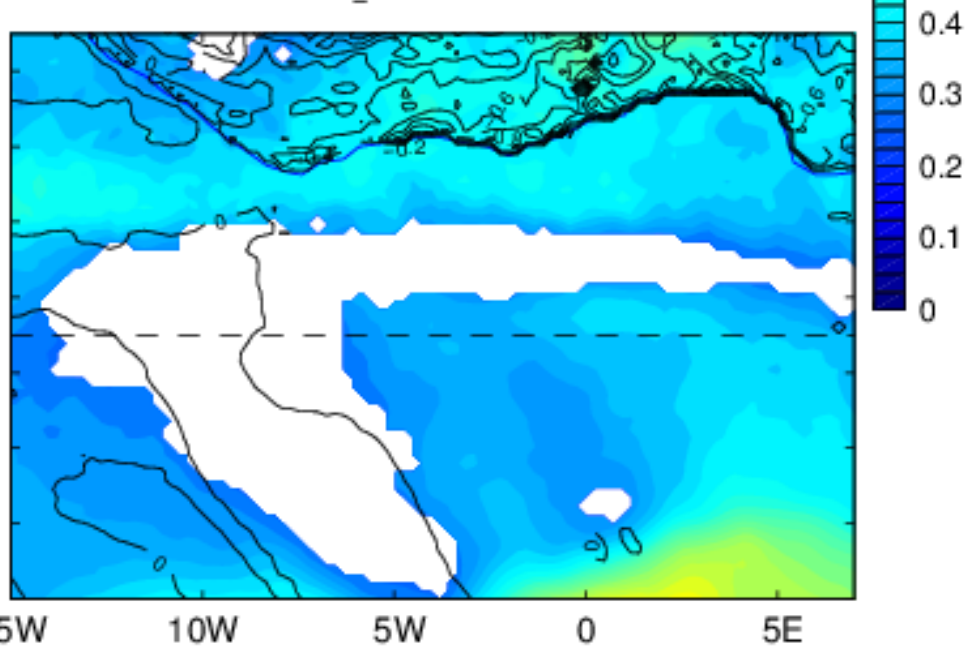

Figure 10: WRF simulation surface pressure (colours) and SST (black contours, intervals of 0.2 $\mathrm{K})$ differences between:

* testing the influence of the SST :

case 1 with SST2 - case 1 (top left), and case 2 - case 2 with SST1 (top right);

$*$ testing the influence of the external forcing :

case 2 - case 1 with SST2 (bottom left), case 1 with SST2 - case 2 (bottom right). 


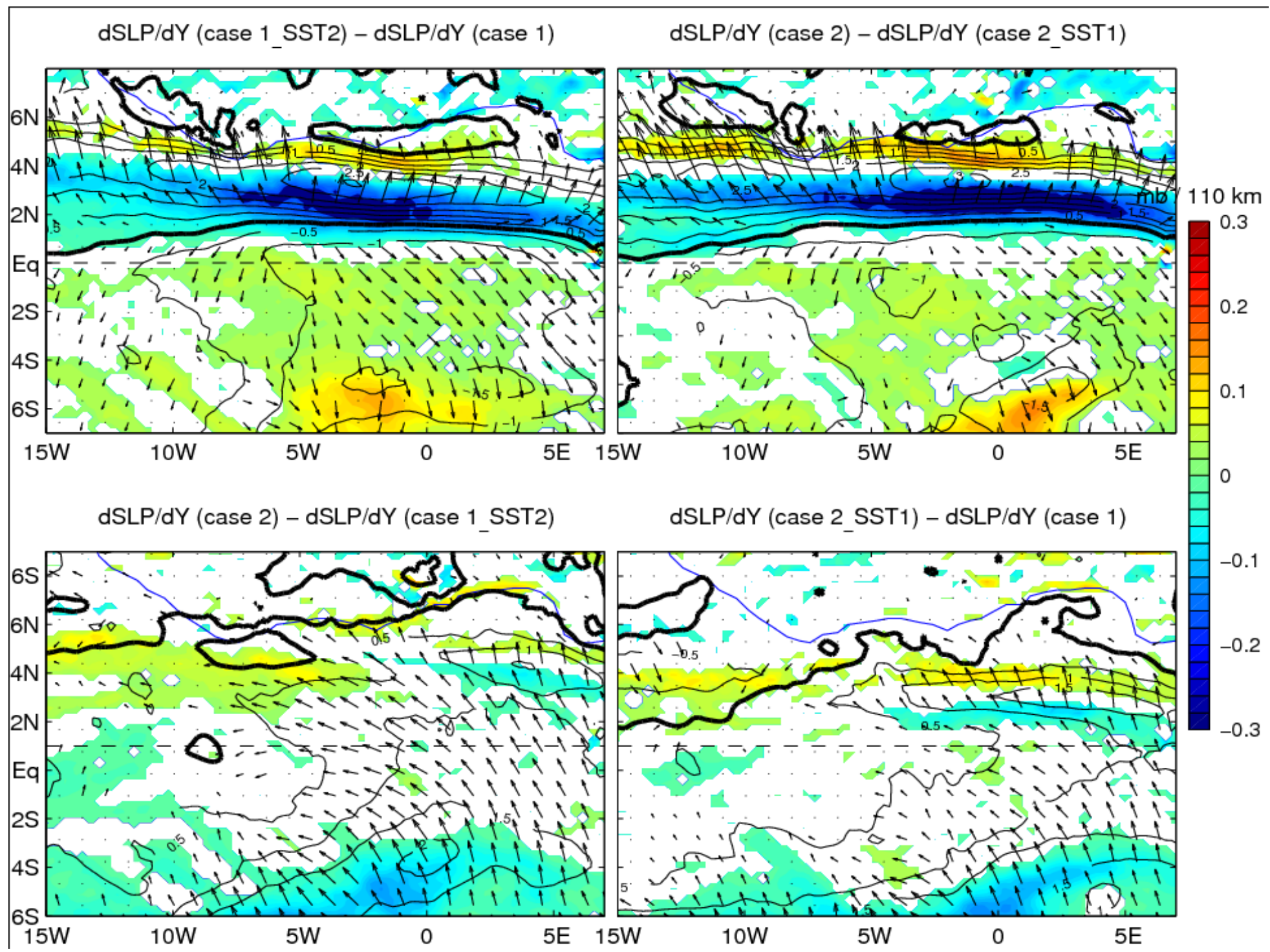

Figure 11: same as Fig. 5 for the absolute value of pressure gradient (shadings) and wind speed (black contours, intervals of $0.5 \mathrm{~m} / \mathrm{s}$, heavy line marks null wind speed difference). 

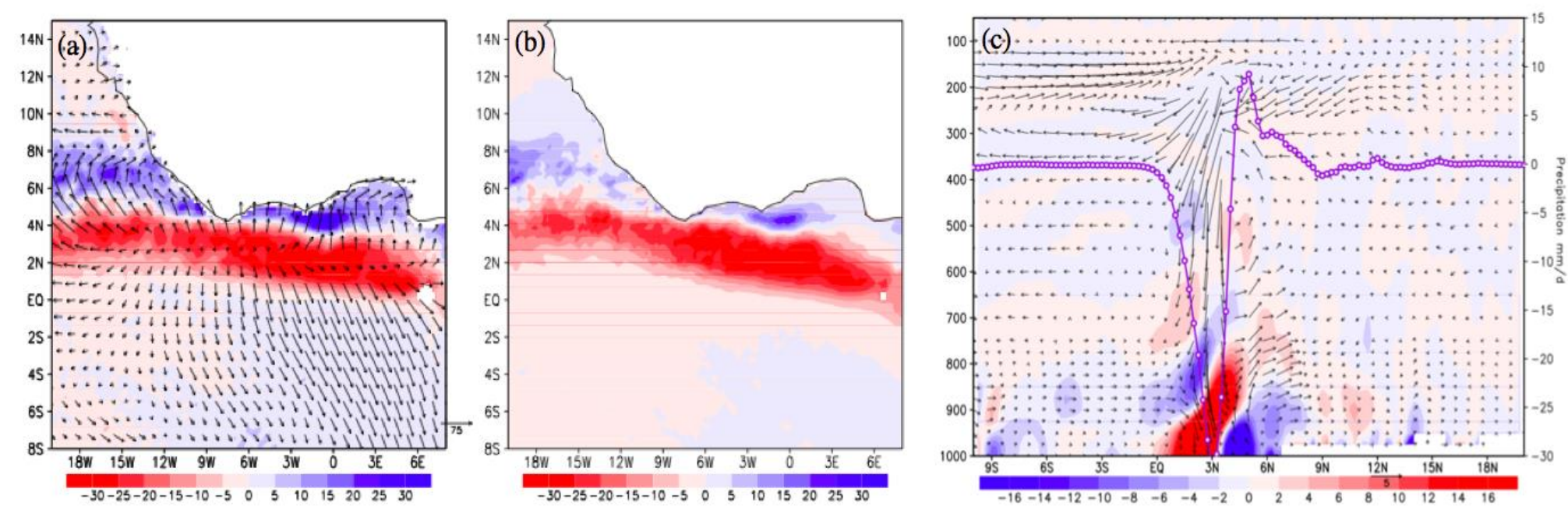

Figure 12: In WRF simulation : testing the influence of the SST with 《Case $2 》$ minus 《Case 2 with SST1 》 for : a) vertically integrated Moisture flux convergence (divergence) in blue (red), in $\mathrm{mm} /$ day, with integrated moisture flux $\left(\mathrm{kg} / \mathrm{m}^{2} / \mathrm{s}\right)$, (b) precipitation (mm/day), (c) zonal average $\left(10^{\circ} \mathrm{W}-0 \mathrm{~W}\right)$ of vertical cross section of horizontal moisture flux divergence (shading, EMBED opendocument. MathDocument. $\left.110^{8} \mathrm{~s}^{-1}\right)$, meridional $(\mathrm{m} / \mathrm{s})-\operatorname{vertical}(\times 100 \mathrm{~Pa} / \mathrm{s})$ 